\title{
Use of Exercise and Structure during Rainbow Trout Rearing
}

\author{
Jill M. Voorhees*, Nathan Huysman, Eric Krebs, Michael E. Barnes \\ Department of Game, Fish and Parks, McNenny State Fish Hatchery, Spearfish, USA \\ Email: *jill.voorhees@state.sd.us
}

How to cite this paper: Voorhees, J.M., Huysman, N., Krebs, E. and Barnes, M.E. (2020) Use of Exercise and Structure during Rainbow Trout Rearing. Open Journal of Applied Sciences, 10, 258-269. https://doi.org/10.4236/ojapps.2020.105020

Received: April 21, 2020

Accepted: May 26, 2020

Published: May 29, 2020

Copyright (อ 2020 by author(s) and Scientific Research Publishing Inc. This work is licensed under the Creative Commons Attribution International License (CC BY 4.0).

http://creativecommons.org/licenses/by/4.0/ (c) (i) Open Access

\begin{abstract}
A combination of two forms of environmental enrichment (in-tank structure and exercise) was evaluated during the hatchery rearing of juvenile rainbow trout Oncorhynchus mykiss. The study used four treatments: 1) neither exercise nor structure, 2) exercise without structure, 3) structure without exercise, and 4) both exercise and structure. Velocities in the unexercised tanks were a constant $12.2 \mathrm{~cm} \cdot \mathrm{s}^{-1}$. Velocities in the exercised tanks alternated weekly with one week at $12.2 \mathrm{~cm} \cdot \mathrm{s}^{-1}$ followed by a week at $30.5 \mathrm{~cm} \cdot \mathrm{s}^{-1}$. Structural enrichment consisted of an array of vertically-suspended aluminum angles. The use of either environmental enrichment technique significantly improved final tank weight, gain, percent gain, and specific growth rate. Feed conversion ratio was significantly and positively influenced only by structure, but fish on the exercise routine were overfed. There were no significant interactions between exercise and structure, indicating that each form of environmental enrichment operates independently. The results of this study indicate fish rearing performance can be improved with the addition of either vertically-suspended aluminum angles or an exercise routine, but the combination of the two techniques may not be needed to improve rainbow trout growth.
\end{abstract}

\section{Keywords}

Routine, Velocity, Oncorhynchus mykiss, Salmonids, Environmental Enrichment

\section{Introduction}

Hatchery rearing conditions can have a significant effect on fish behavior and physiology [1]. Enriching typically barren hatchery tanks, raceways, and other rearing units has been shown to be beneficial during hatchery rearing [2]. Environmental enrichment may also improve survival of hatchery-reared fish re- 
leased into the natural environment [3]. Several types of environmental enrichment during fish production have been identified, including physical, dietary, sensory, social, and occupational categories [4] [5]. Physical enrichment is the addition of structure to the rearing unit. Dietary enrichment involves changes to the delivery or type of food. Sensory enrichment is sensory stimulation and social enrichment involves interactions among fish. Occupational enrichment is primarily exercise. These categories overlap, however. Physical enrichment, such as adding structure to a tank, likely leads to sensory enrichment as the fish senses are stimulated, social enrichment as fish behavior changes, and occupational enrichment as the structure impacts in-tank water velocities and swimming exercise [6] [7].

Considerable attention has focused on physical and occupational enrichment. Structures added to hatchery tanks include woody material [8] [9] [10] [11] [12] [13] [14]; concrete and rocks [3] [11] [15] [16], and plastic plants [17] [18] [19] [20] [21]. However, these physical environmental techniques are largely incompatible with production-level hatchery rearing because they impede tank hydraulic self-cleaning. This leads to the accumulation of uneaten feed and feces, which increases hatchery labor demands and the risk of potential disease outbreaks [22] [23] [24]. Recently however, vertically-suspended structures which have positively impact fish growth while still allowing for hydraulic self-cleaning have been developed and evaluated [25]-[34].

Exercise as a form of occupational environmental enrichment occurs when the fish are forced to swim by adjusting water velocities. Exercise is generally regarded as beneficial by improving swimming stamina, increasing hatchery growth, and positively impacting fish behavior [35]-[41]. Continual exercise for long durations may lead to exercise fatigue however [42] [43] [44] [45]. Routines that balance exercise with rest periods are likely more beneficial [46]-[51].

Despite the plethora of studies examining physical and occupational enrichment, only two studies have examined them in combination. Kientz and Barnes [25] used vertically-suspended structure and two water velocities. However, the two velocities were relatively similar and only one type of structure was used. In addition, the Kientz and Barnes [25] study was of relatively short duration. More recently, Voorhees et al. [44] used two dissimilar velocities and three types of structure and reported significant interactions between the velocity (exercise) and the structure type. Both Kientz and Barnes [25] and Voorhees et al. [44] used constant exercise. There have been no studies evaluating a combination of an exercise routine and physical enrichment during hatchery rearing. Thus, the objective of this study was to evaluate the effect of an exercise routine and physical enrichment on hatchery rearing performance.

\section{Methods}

This experiment was conducted at McNenny State Fish Hatchery, rural Spearfish, South Dakota, USA using degassed and aerated well-water (constant tem- 
perature $11^{\circ} \mathrm{C}$; total hardness as $\mathrm{CaCO}_{3}, 360 \mathrm{mg} \cdot \mathrm{L}^{-1}$; alkalinity as $\mathrm{CaCO}_{3}, 210$ $\mathrm{mg} \cdot \mathrm{L}^{-1} ; \mathrm{pH}, 7.6$; total dissolved solids, $\left.390 \mathrm{mg} \cdot \mathrm{L}^{-1}\right)$. Approximately $2400(8.4 \mathrm{~kg})$ Shasta strain rainbow trout Oncorhynchus mykiss (mean $\pm \mathrm{SE}$, initial weight $=$ $3.6 \pm 0.2 \mathrm{~g}$, initial length $69 \pm 1 \mathrm{~mm}, n=30$ ) were placed into each of 16 circular tanks (1.8 m diameter $\times 0.6 \mathrm{~m}$ deep; $0.4 \mathrm{~m}$ water depth) on May 31, 2008. The experiment started the following day and lasted 109 days.

Four treatments were used in this study: 1) neither exercise nor structure, 2) exercise routine without structure, 3) vertically-suspended structure without exercise, and 4) both exercise and structure. The vertically-suspended structure was an array of four aluminum angles $(2.5 \mathrm{~cm}$ wide on each angle side $\times 57.15$ $\mathrm{cm}$ long) as described by Krebs et al. [27] which were suspended through a corrugated black plastic cover [52] (Figure 1). The angles were placed so the peak of the angle faced into the water current. Velocities in the unexercised tanks were a constant $12.2 \mathrm{~cm} \cdot \mathrm{s}^{-1}$. Velocities in the exercise routine tanks alternated weekly with one week at $12.2 \mathrm{~cm} \cdot \mathrm{s}^{-1}$ followed by a week at $30.5 \mathrm{~cm} \cdot \mathrm{s}^{-1}$. Velocities were adjusted by rotating the incoming water spray bar and were measured using a flow probe (FP111 Global Water Flow Probe, Global Water, College Station, Texas, USA). All readings were taken directly behind the spray bar about $0.2 \mathrm{~m}$ deep (half-way in water column).

All fish were fed $1.5 \mathrm{~mm}$; extruded floating trout diet (Protec, Skretting USA, Tooele, Utah, USA) every 15 minutes during daylight hours by means of automatic feeders. Feeding rates were determined by the hatchery constant method [53], with and expected feed conversion ratio of 1.1. Unexercised tanks were fed at a projected growth rate at or slightly above satiation $\left(0.08 \mathrm{~cm} \cdot \mathrm{d}^{-1}\right)$, while exercised tanks were fed at a higher projected growth rate $\left(0.09 \mathrm{~cm} \cdot \mathrm{d}^{-1}\right)$ to compensate for the increased energy demands from exercise [40].

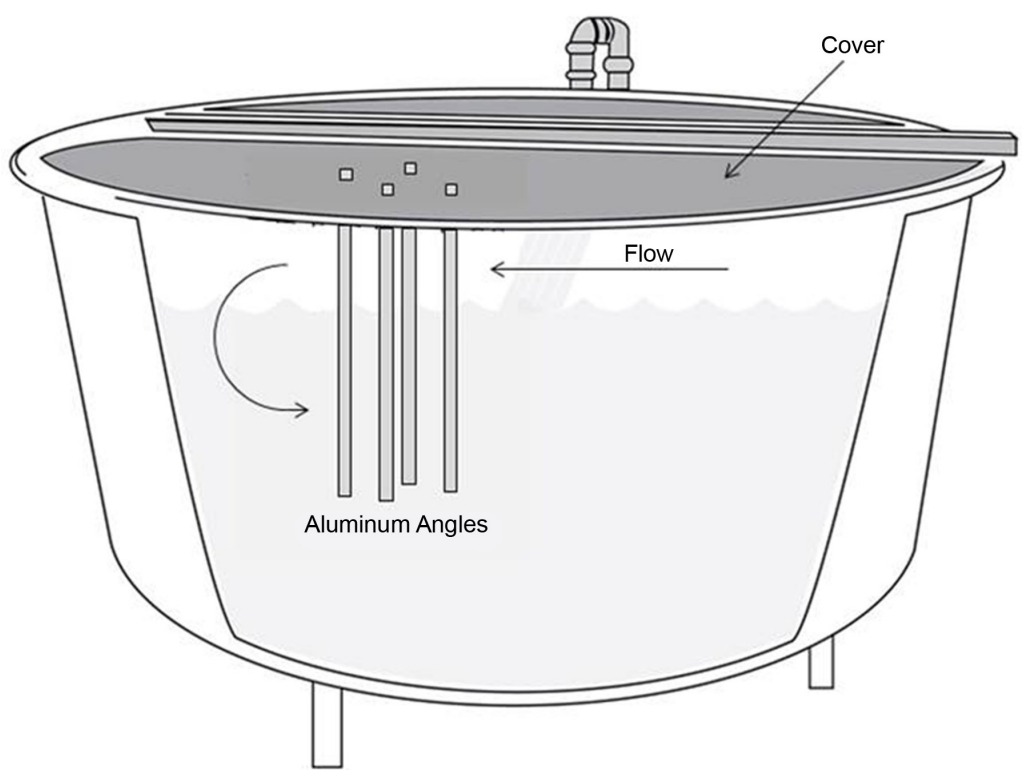

Figure 1. Circular tank with suspended array of four aluminum angles, with the peak of the angle facing in the direction of the water flow. 
At the completion of the experiment total tank weight was recorded to the nearest $0.1 \mathrm{~kg}$. Ten individual fish from each tank were also weighed to the nearest $0.1 \mathrm{~g}$, and measured (total length) to the nearest $1.0 \mathrm{~mm}$. Gain (1), percent gain (2), specific growth rate (SGR; 3), feed conversion ratio (FCR; 4), and condition factor $(\mathrm{K} ; 5)$ were calculated using the following formulas:

$$
\begin{gathered}
\text { Gain }=\text { end weight }- \text { start weight } \\
\text { Percent gain }(\%)=100 * \frac{\text { gain }}{\text { start weight }} \\
\text { SGR }=100 * \frac{\ln (\text { end weight })-\ln (\text { start weight })}{\text { number of days }} \\
\text { Feed conversion ratio(FCR })=\frac{\text { food fed }}{\text { gain }} \\
\mathrm{K}=10^{5} * \frac{\text { fish weight }}{\text { fish length }^{3}}
\end{gathered}
$$

Data were analyzed using SPSS (24.0) statistical program (IBM, Armonk, New York, USA) with significance predetermined at $p<0.05$. Tanks were the experimental unit, not the individual fish. Two-way analysis of variance (ANOVA) was performed and if a significant difference was observed, post hoc means separations tests were conducted using Tukey HSD.

\section{Results}

No significant interactions were observed between exercise and structure in any variables. Final tank weight, gain, percent gain, and feed conversion ratio were all significantly improved in the tanks containing vertically-suspended structure (Table 1). Final tank weight, gain, and percent gain were also significantly improved in the tanks receiving the exercise routine. However, exercised tanks received significantly more feed and had a significantly greater feed conversion ratio. Mortality was less than $1 \%$ and was not significantly different among the treatments.

Individual fish in tanks containing structure were significantly heavier, longer, and greater specific growth rate (Table 2). Exercised fish had a significantly greater total lengths and specific growth rates, but individual fish weights were not significantly different. Condition factor was not significantly different among any of the treatments.

\section{Discussion}

The lack of interaction between structure and exercise observed in this study indicates that these two forms of environmental enrichment act independently of each other. There appears to be no combined effect. These results are consistent with those reported by Kientz and Barnes [25], who used vertically-suspended rods for 51 days with juvenile rainbow trout at two continuous velocities (2.0 body lengths $(\mathrm{BL}) \cdot \mathrm{s}^{-1}$ and $2.75 \mathrm{BL} \cdot \mathrm{s}^{-1}$ ) and also reported no interactions between 
Table 1. Mean $\left( \pm S E\right.$ ) final tank weight, gain, food fed, feed conversion ratio $\left(F C R^{a}\right)$, and percent mortality of rainbow trout reared with or without vertically-suspended strcture and with or without an exercise routine $(n=4) .^{\text {b }}$

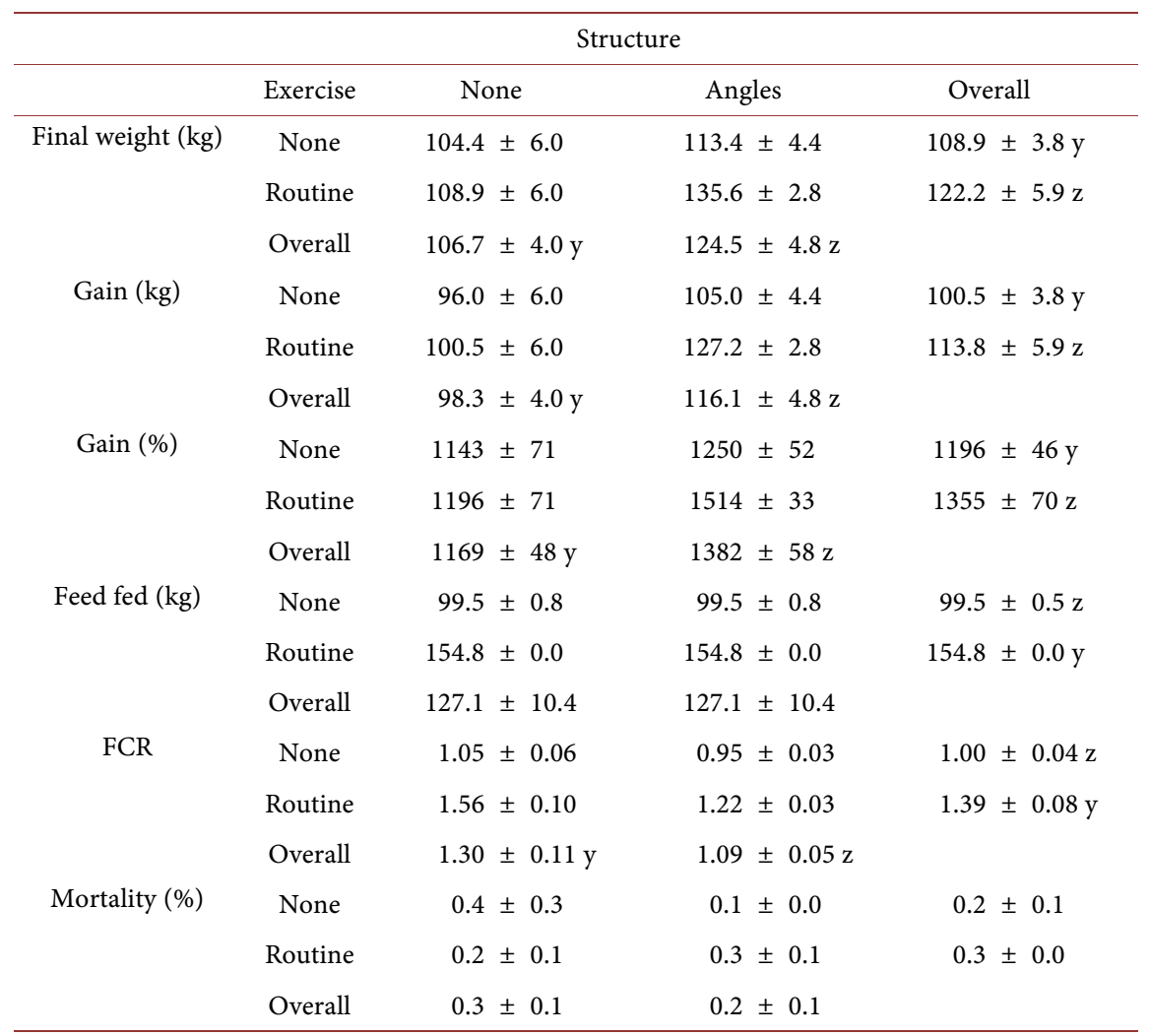

${ }^{\mathrm{a}} \mathrm{FCR}=$ food fed/gain; ${ }^{\mathrm{b} O v e r a l l ~ m e a n s ~ w i t h ~ d i f f e r e n t ~ l e t t e r s ~ i n ~ s a m e ~ c o l u m n ~ o r ~ r o w ~ d i f f e r ~ s i g n i f i c a n t l y ~}(p<$ $0.05)$.

Table 2. Individual mean ( $\pm \mathrm{SE}$ ) total length, weight, speicic growth rate $\left(\mathrm{SGR}^{\mathrm{a}}\right)$, and condition factor $\left(\mathrm{K}^{\mathrm{b}}\right)$ of rainbow trout reared with or without vertically-suspended strcture and with or without an exercise routine $(n=4){ }^{c}$

\begin{tabular}{ccccc}
\hline \multicolumn{5}{c}{ Structure } \\
\hline & Exercise & None & Angles & Overall \\
\hline Total length $(\mathrm{mm})$ & None & $156 \pm 2$ & $164 \pm 1$ & $160 \pm 2 \mathrm{y}$ \\
& Routine & $156 \pm 3$ & $173 \pm 2$ & $165 \pm 4 \mathrm{z}$ \\
& Overall & $156 \pm 2 \mathrm{y}$ & $169 \pm 2 \mathrm{z}$ & \\
Weight (g) & None & $45.2 \pm 2.9$ & $55.9 \pm 0.8$ & $50.5 \pm 2.5$ \\
& Routine & $47.9 \pm 3.9$ & $63.0 \pm 3.2$ & $55.5 \pm 3.7$ \\
& Overall & $46.6 \pm 2.3 \mathrm{y}$ & $59.4 \pm 2.1 \mathrm{z}$ & \\
& None & $2.33 \pm 0.05$ & $2.41 \pm 0.03$ & $2.37 \pm 0.03 \mathrm{y}$ \\
& Routine & $2.37 \pm 0.05$ & $2.57 \pm 0.02$ & $2.47 \pm 0.05 \mathrm{z}$ \\
& Overall & $2.35 \pm 0.03 \mathrm{y}$ & $2.49 \pm 0.04 \mathrm{z}$ & \\
$\mathrm{K}$ & None & $1.19 \pm 0.03$ & $1.26 \pm 0.01$ & $1.23 \pm 0.02$ \\
& Routine & $1.25 \pm 0.04$ & $1.21 \pm 0.02$ & $1.23 \pm 0.02$ \\
& Overall & $1.22 \pm 0.03$ & $1.24 \pm 0.01$ & \\
\hline
\end{tabular}

${ }^{\text {aSGR }}=100 \times(\ln ($ end weight $)-\ln ($ start weight $)) /($ (number of days $\left.)\right) ;{ }^{b} \mathrm{~K}=10^{5} \times\left((\right.$ fish weight $\left.) /(\text { fish length })^{3}\right)$; 'Overall means with different letters in same column or row differ significantly $(p<0.05)$. 
structure and exercise. However, Voorhees et al. [45] did report a significant interaction. Vertically-suspended rods and vertically-suspended plastic spheres were used for 119 days at two continuous velocities (approximately $1.7 \mathrm{BL} \cdot \mathrm{s}^{-1}$ and $4.0 \mathrm{BL} \cdot \mathrm{s}^{-1}$ ) and found significantly poorer rearing performance in exercised trout reared without structure. It is likely however, that the continuous exercise regime used by Voorhees et al. [45] led to the significant interaction between velocity and exercise by causing exercise fatigue [42] [43] [44] [45], unlike the intermittent exercise protocol used in this study.

The positive effects of the exercise routine used in this study on trout growth and feeding efficiency are not surprising. Farrell et al. [47] observed that rainbow trout subjected to a routine of ten hours of exercise and two hours of rest were larger than unexercised fish. Liu et al. [51] exercised Ya-fish Schizothoraxprenati for eight hours per day for two days per week and reported improved growth in the fish receiving moderate exercise. However, at higher velocity levels that produced vigorous exercise, positive effects on fish rearing performance were not observed. This is similar to the results of other studies using high velocities for exercise or not allowing for any rest periods [25] [44] [45], which all likely produced exercise fatigue [42] [43] [44] [45]. In general, exercise has been shown to be beneficial for fish by reducing stress [54] [55] [56], decreasing agonistic behavior [36] [57], increasing swimming performance [48] [49] [58] [59], increasing disease resistance [50] [51] and increasing post-stocking survival [60].

The positive results in rearing performance observed in this study with the use of vertically-suspended structure as a form of environmental enrichment are also not surprising. The benefits of using a variety of vertically-suspended structures during hatchery rearing have been well-documented [25] [26] [27] [29] [30] [32] [34]. It must be noted however, that the results from using structure in this study differ from those of White et al. [28], Huysman et al. [31], and Jones et al. [33]. These differences could be due to differences in the size and species of fish used in each experiment, as well as the duration of each study.

At 109 days this study was considerably longer than other exercise experiments, which typically last four to six weeks [36] [47] [50] [51] [54] [57] [59]-[66]. However, the long duration of this study may have influenced the results because final tank loadings may have become excessive. Huysman et al. [31] used identical tanks and suggested that their final tank weights of nearly 110 $\mathrm{kg}$ may have led to density-dependent reduced growth rates in the faster-growing tanks containing structure. By allowing slower-growing fish in other treatments the opportunity to catch-up in size, the long study duration may have precluded any determination of significant differences among the treatments. Final tank weights in the current study were nearly $140 \mathrm{~kg}$, which was $30 \mathrm{~kg}$ greater than Huysman et al. [31] densities may have been too high.

Despite the relatively high loading densities, the feed conversion ratios observed in this experiment are similar to those previously reported for rainbow trout [25] [28] [30] [31] [32] [33] [45]. At 2.3 to 2.6, the specific growth rates, which is basically the percentage growth per day of fish, in this study were also 
similar to those reported by Huysman et al. [32] and Voorhees et al. [45]. Condition factors were also similar to those reported previously for rainbow trout [25] [30] [31] [33].

\section{Conclusion}

In conclusion, the results of this study indicate fish rearing performance can be improved with the addition of either vertically-suspended aluminum angles or an exercise routine, but the combination of the two techniques may not be needed to improve rainbow trout growth. Conversely, the combination of the two types of environmental enrichment is also not problematic and may provide benefits later in the production cycle or after stocking. Future research needs indicated by this study include investigations into different exercise regimes, the interactions between rearing densities and environmental enrichment, the effects of single or multiple environmental enrichment techniques on post-stocking survival, and the impacts of environmental enrichment on rearing unit carrying capacities.

\section{Acknowledgements}

Alissa Muggli and Sarah White generously assisted with this study.

\section{Conflicts of Interest}

The authors declare no conflicts of interest regarding the publication of this paper.

\section{References}

[1] Brydges, N.M. and Braithwaite, V.A. (2009) Does Environmental Enrichment affect the Behaviour of Fish Commonly Used in Laboratory Work? Applied Animal Behaviour Science, 118, 137-143. https://doi.org/10.1016/j.applanim.2009.02.017

[2] Brockmark, S., Neregård, L., Bohlin, T., Björnsson, B.T. and Johnsson, J.I. (2007) Effects of Rearing Density and Structural Complexity on the Pre- and Postrelease Performance of Atlantic Salmon. Transactions of the American Fisheries Society, 136, 1453-1462. https://doi.org/10.1577/T06-245.1

[3] Salvanes, A.G.V., Moberg, O., Ebbesson, L.O., Nilsen, T.O., Jensen, K.H. and Braithwaite, V.A. (2013) Environmental Enrichment Promotes Neural Plasticity and Cognitive Ability in Fish. Proceedings of the Royal Society B: Biological Sciences, 280, Article ID: 20131331. https://doi.org/10.1098/rspb.2013.1331

[4] Gerber, B., Stamer, A. and Stadtlander, T. (2015) Environmental Enrichment and its Effects on Welfare in Fish. Review. Research Institute of Organic Agriculture (FiBL), CH-Frick.

[5] Näslund, J. and Johnsson, J.I. (2016) Environmental Enrichment for Fish in Captive Environments: Effects of Physical Structures and Substrates. Fish and Fisheries, 17, 1-30. https://doi.org/10.1111/faf.12088

[6] Moine, J., Barnes, M.E., Kientz, J. and Simpson, G. (2016) Flow Pattern in Circular Rearing Tanks Containing Vertical Structure. Journal of Fisheries and Livestock Production, 4, 4. https://doi.org/10.4172/2332-2608.1000204 
[7] Muggli, A.M., Barnes, J.M. and Barnes, M.E. (2019) Vertically-Suspended Environmental Enrichment Alters the Velocity Profiles of Circular Fish Rearing Tanks. World Journal of Engineering and Technology, 7, 208-226. https://doi.org/10.4236/wjet.2019.71014

[8] Berejikian, B.A., Tezak, E.P., Flagg, T.A., LaRae, A.L., Kummerow, E. and Mahnken, C.V.W. (2000) Social Dominance, Growth, and Habitat Use of Age-0 Steelhead (Oncorhynchus mykiss) Grown in Enriched and Conventional Hatchery Rearing Environments. Canadian Journal of Fisheries and Aquatic Sciences, 57, 628-636. https://doi.org/10.1139/f99-288

[9] Maynard, D., Berejikian, B., Flagg, T. and Mahnken, C. (2001) Development of a Natural Rearing System to Improve Supplemental Fish Quality. 1996-1998 Progress Report. https://doi.org/10.2172/789584

[10] Berejikian, B.A. and Tezak, E.P. (2005) Rearing in Enriched Hatchery Tanks Improves Dorsal Fin Quality of Junvenile Steelhead. North American Journal of Aquaculture, 67, 289-293. https://doi.org/10.1577/A05-002.1

[11] Tatara, C.P., Riley, S.C. and Scheurer, J.A. (2008) Environmental Enrichment in Steelhead (Oncorhynchus mykiss) Hatcheries: Field Evaluation of Aggression, Foraging, and Territoriality in Natural and Hatchery Fry. Canadian Journal of Fisheries and Aquatic Sciences, 65, 744-753. https://doi.org/10.1139/f08-004

[12] Watz, J., Calles, O., Carlsson, N., Collin, T., Huusko, A., Johnsson, J., Nilsson, P.A., Norrgård, J. and Nyqvist, D. (2019) Wood Addition in the Hatchery and River Environments Affects Post-release Performance of Overwintering Brown Trout. Freshwater Biology, 64, 71-80. https://doi.org/10.1111/fwb.13195

[13] Zydlewski, G.B., Foott, J.S., Nichols, K., Hamelberg, S., Zydlewski, J. and Björnsson, B.T. (2003) Enhanced Smolt Characteristics of Steelhead Trout Exposed to Alternative Hatchery Conditions During the Final Months of Rearing. Aquaculture, 222, 101-117. https://doi.org/10.1016/S0044-8486(03)00105-4

[14] Maynard, D.J., Flagg, T.A., Iwamoto, R.N. and Mahnken, C.V.W. (2004) A Review of Recent Studies Investigating Seminatural Rearing Strategies as a Tool for Increasing Pacific Salmon Postrelease Survival. American Fisheries Society Symposium, 44, 569-580.

[15] Bosakowski, T. and Wagner, E.J. (1995) Experimental Use of Cobble Substrates in Concrete Raceways for Improving Fin Condition of Cutthroat (Oncorhynchus clarki) and Rainbow Trout (O. mykiss). Aquaculture, 130, 159-165.

https://doi.org/10.1016/0044-8486(94)00223-B

[16] Jonsson, B. and Jonsson, N. (2014) Early Environment Influences Later Performance in Fishes. Journal of Fish Biology, 85, 151-188. https://doi.org/10.1111/jfb.12432

[17] Lee, J.S.F. and Berejikian, B.A. (2008) Effects of the Rearing Environment on Average Behaviour and Behavioural Variation in Steelhead. Journal of Fish Biology, 72, 1736-1749. https://doi.org/10.1111/j.1095-8649.2008.01848.x

[18] Strand, D.A., Utne-Palm, A.C., Jakobsen, P.J., Braithwaite, V.A., Jensen, K.H. and Salvanes, A.G.V. (2010) Enrichment Promotes Learning in Fish. Marine Ecology Progress Series, 412, 273-282. https://doi.org/10.3354/meps08682

[19] Näslund, J., Rosengren, M., Del Villar, D., Gansel, L., Norrgård, J.R., Persson, L., Winkowski, J.J. and Kvingedal, E. (2013) Hatchery Tank Enrichment Affects Cortisol Levels and Shelter-seeking in Atlantic Salmon (Salmo salar). Canadian Journal of Fisheries and Aquatic Sciences, 70, 585-590. https://doi.org/10.1139/cjfas-2012-0302 
[20] Bergendahl, I.A., Miller, S., Depasquale, C., Giralico, L. and Braithwaite, V.A. (2017) Becoming a Better Swimmer: Structural Complexity Enhances Agility in Captive-Reared Fish. Journal of Biology, 90, 1112-1117. https://doi.org/10.1111/jfb.13232

[21] Self, K.E., Schreck, C.B., Cogliati, K.M., Billman, E.J. and Noakes, D.L.G. (2018) The Effect of Rearing Structures on Behaviour and Movement of Juvenile Steelhead Oncorhynchus mykiss. Journal of Fish Biology, 93, 449-454. https://doi.org/10.1111/jfb.13657

[22] Krebs, J., Crank, K.M., Krebs, E. and Barnes, M.E. (2017) Use of Bottom Structure and Tank Cover During Rainbow Trout Rearing in Circular Tanks. Journal of Fish Fisheries and Livestock Production, 5, 3. https://doi.org/10.4172/2332-2608.1000247

[23] Baynes, S.M. and Howell, B.R. (1993) Observations on the Growth, Survival and Disease Resistance of Juvenile Common Sole, Soleasolea(L.), Fed Mytilus edulis L. Aquaculture Research, 24, 95-100. https://doi.org/10.1111/j.1365-2109.1993.tb00831.x

[24] Tuckey, L.M. and Smith, T.I.J. (2001) Effects of Photoperiod and Substrate on Larval Development and Substrate Preference of Juvenile Southern Flounder, Paralichthyslethostigma. Journal of Applied Aquaculture, 11, 1-20. https://doi.org/10.1300/J028v11n01 02

[25] Kientz, J.L. and Barnes, M.E. (2016) Structural Complexity Improves the Rearing Performance of Rainbow Trout in Circular Tanks. North American Journal of Aquaculture, 78, 203-207. https://doi.org/10.1080/15222055.2016.1159629

[26] Kientz, J.L., Crank, K.M. and Barnes, M.E. (2018) Enrichment of Circular Tanks with Vertically Suspended Strings of Colored Balls Improves Rainbow Trout Rearing Performance. North American Journal of Aquaculture, 80, 162-167. https://doi.org/10.1002/naaq.10017

[27] Krebs, E., Huysman, N., Voorhees, J.M. and Barnes, M.E. (2018) Suspended Arrays Improve Rainbow Trout Growth During Hatchery Rearing in Circular Tanks. International Journal of Aquaculture and Fishery Science, 4, 27-30. https://doi.org/10.17352/2455-8400.000040

[28] White, S.C., Barnes, M.E., Krebs, E., Huysman, N. and Voorhees, J.M. (2018) Addition of Vertical Enrichment Structures Does Not Improve Growth of Three Salmonid Species during Hatchery Rearing. Journal of Marine Biology and Aquaculture, 4, 48-52. https://doi.org/10.15436/2381-0750.18.1957

[29] White, S.C., Krebs, E., Huysman, N., Voorhees, J.M. and Barnes, M.E. (2019) Use of Suspended Plastic Conduit Arrays During Brown Trout and Rainbow Trout Rearing in Circulars. North American Journal of Aquaculture, 81, 101-106. https://doi.org/10.1002/naaq.10076

[30] Crank, K.M., Kientz, J.L. and Barnes, M.E. (2019) An Evaluation of Vertically Suspended Environmental Enrichment Structures during Rainbow Trout Rearing. North American Journal of Aquaculture, 81, 94-100. https://doi.org/10.1002/naaq.10064

[31] Huysman, N., Krebs, E., Voorhees, J.M. and Barnes, M.E. (2019) Use of Large Vertically-Suspended Rod Array in Circular Tanks during Juvenile Rainbow Trout Rearing. International Journal of Marine Biology and Research, 4, 1-5.

[32] Huysman, N., Krebs, E., Voorhees, J.M. and Barnes, M.E. (2019) Use of Two Vertically-suspended Environmental Enrichment Arrays during Rainbow Trout Rearing in Circular Tanks. International Journal of Innovative Studies in Aquatic Biology and Fisheries, 5, 25-30. https://doi.org/10.20431/2454-7670.0501005 
[33] Jones, M.D., Krebs, E., Huysman, N., Voorhees, J.M. and Barnes, M.E. (2019) Rearing Performance of Atlantic Salmon Grown in Circular Tanks with Vertically-suspended Environmental Enrichment. Open Journal of Animal Sciences, 9, 249-257. https://doi.org/10.4236/ojas.2019.92021

[34] Rosburg, A.J., Fletcher, B.L., Barnes M.E., Treft, C.E. and Bursell, B.R. (2019) Vertically-suspended Environmental Enrichment Structures Improve the Growth of Juvenile Landlocked Fall Chinook Salmon. International Journal of Innovative Studies in Aquatic Biology and Fisheries, 5, 17-24.

https://doi.org/10.20431/2454-7670.0501004

[35] Davison, W. (1997) The Effects of Exercise Training on Teleost Fish, a Review of Recent Literature. Comparative Biochemistry and Physiology Part A: Physiology, 117, 67-75. https://doi.org/10.1016/S0300-9629(96)00284-8

[36] Christiansen, J.S. and Jobling, M. (1989) The Behavior and the Relationship between Food Intake and Growth of Juvenile Arctic Charr, Salvelinus alpinus L., Subjected to Sustained Exercise. Canadian Journal of Zoology, 68, 2185-2191. https://doi.org/10.1139/z90-303

[37] Christiansen, J.S., Ringø, E. and Jobling, M. (1989) Effects of Sustained Exercise on Growth and Body Composition of First-Feeding Fry of Arctic Charr, Salvelinus alpinus (L.). Aquaculture, 79, 329-335. https://doi.org/10.1016/0044-8486(89)90474-2

[38] Olla, B.L., Davis, M.W. and Ryer, C.H. (1994) Behvaioural Deficits in Hatchery-Reared Fish: Potential Effects on Survival Following Release. Aquaculture and Fisheries Management, 25, 19-34.

[39] Brown, C. and Day, R.L. (2002) The Future of Stock Enhancements: Lessons for Hatchery Practice from Conservation Biology. Fish and Fisheries, 3, 79-94. https://doi.org/10.1046/j.1467-2979.2002.00077.x

[40] Parker, T.M. and Barnes, M.E. (2015) Effects of Different Water Velocities on the Hatchery Rearing Performance and Recovery from Transportation of Rainbow Trout Fed Two Different Rations. Transactions of the American Fisheries Society, 144, 882-890. https://doi.org/10.1080/00028487.2015.1047533

[41] Gorle, J.M.R., Terjesen, B.F., Mota, V.C. and Summerfelt, S. (2018) Water Velocity in Commercial RAS Culture Tanks for Atlantic Salmon Smolt Production. Aquaculture Engineering, 81, 89-100. https://doi.org/10.1016/j.aquaeng.2018.03.001

[42] Voorhees, J.M., Barnes, M.E., Chipps, S.R. and Brown, M.L. (2018) Dietary Bioprocessed Soybean Meal Does Not Affect the Growth of Exercised Juvenile Rainbow Trout (Oncorhynchus mykiss). Journal of Animal Research and Nutrition, 3, 6. https://doi.org/10.21767/2572-5459.100050

[43] Voorhees, J.M., Barnes, M.E., Chipps, S.R. and Brown, M.L. (2018) Rearing Performance of Juvenile Brown Trout (Salmo trutta) Subjected to Exercise and Dietary Bioprocessed Soybean Meal. Open Journal of Animal Science, 8, 303-308. https://doi.org/10.4236/ojas.2018.83023

[44] Voorhees, J.M., Barnes, M.E., Chipps, S.R. and Brown, M.L. (2019) Effects of Exercise and Bioprocessed Soybean Meal Diets during Rainbow Trout Rearing. The Open Biology Journal, 7, 1-13. https://doi.org/10.2174/1874196701907010001

[45] Voorhees, J.M., Huysman, N., Krebs, E. and Barnes, M.E. (2020) Influence of Water Velocity and Vertically-suspended Structures on Rainbow Trout Rearing Performance. Open Journal of Animal Sciences, 10, 152-161. https://doi.org/10.4236/ojas.2020.101008

[46] Davison, W. (1989) Training and its Effects on Teleost Fish. Comparative Biochemistry and Physiology Part A: Physiology, 94, 1-10. 
https://doi.org/10.1016/0300-9629(89)90775-5

[47] Farrell, A.P., Johansen, J.A., Steffensen, J.F., Moyes, C.D., West, T.G. and Suarez, R.K. (1990) Effects of Exercise Training and Coronary Ablation on Swimming Performance, Heart Size, and Cardiac Enzymes in Rainbow Trout, Oncorhynchus mykiss. Canadian Journal of Zoology, 68, 1174-1179. https://doi.org/10.1139/z90-174

[48] Anttila, K., Mänttäri, S. and Järvilehto, M. (2006) Effects of Different Training Protocols on $\mathrm{Ca}^{2+}$ Handling and Oxidative Capacity in Skeletal Muscle of Atlantic Salmon (Salmo salarL.). Journal of Experimental Biology, 209, 2971-2978. https://doi.org/10.1242/jeb.02341

[49] Anttila, K., Jokikokko, E., Erkinaro, J., Järvilehto, M. and Mänttäri, S. (2011) Effects of Training on Functional Variables of Muscles in Reared Atlantic Salmon Salmo salar Smolts: Connection to Downstream Migration Pattern. Journal of Fish Biolo$g y$, 78, 522-566. https://doi.org/10.1111/j.1095-8649.2010.02871.x

[50] Castro, V., Grisdale-Helland, B., Helland, S.J., Kristensen, T., Jørgensen, S.M., Helgerud, J., Claireaux, G., Farrell, A.P., Krasnov, A. and Takle, H. (2011) Aerobic Training Stimulates Growth and Promotes Disease Resistance in Atlantic Salmon (Salmo salar). Comparative Biochemistry and Phisiology, Part A, 160, 278-290. https://doi.org/10.1016/j.cbpa.2011.06.013

[51] Liu, G., Wu, Y., Qin, X., Shi, X. and Wang, X. (2018) The Effect of Aerobic Exercise Training on Growth Performance, Innate Immune Response, and Disease Resistance in Juvenile Schizothoraxprenanti. Aquaculture, 486, 18-25. https://doi.org/10.1016/j.aquaculture.2017.12.006

[52] Walker, L.M., Parker, T.M. and Barnes, M.E. (2016) Full and Partial Overhead Tank Cover Improves Rainbow Trout Rearing Performance. North American Journal of Aquaculture, 78, 20-24. https://doi.org/10.1080/15222055.2015.1090504

[53] Buterbaugh, G.L. and Willoughby, H. (1967) A Feeding Guide for Brook, Brown, and Rainbow Trout. The Progressive Fish-Culturist, 29, 210-215. https://doi.org/10.1577/1548-8640(1967)29[210:AFGFBB]2.0.CO;2

[54] Woodward, J.J. and Smith, L.S. (1985) Exercise Training and the Stress Response in Rainbow Trout, Salmo gairdneri Richardson. Journal of Fish Biology, 26, 435-447. https://doi.org/10.1111/j.1095-8649.1985.tb04283.x

[55] Barrett, B.A. and McKeown, B.A. (1988) Growth Hormone Response to Sustained Swimming in Exercise-Acclimated Steelhead Trout, Salmo gairdneri. Journal of Fish Biology, 32, 799-800. https://doi.org/10.1111/j.1095-8649.1988.tb05421.x

[56] Palstra, A.P. and Planas, J.V. (2011) Fish Under Exercise. Fish Physiology and Biochemistry, 37, 259-272. https://doi.org/10.1007/s10695-011-9505-0

[57] Jørgensen, E.H. and Jobling, M. (1993) The Effects of Exercise on Growth, Food Utilisation and Osmoregulatory Capacity of Juvenile Atlantic Salmon, Salmo salar. Aquaculture, 116, 233-246. https://doi.org/10.1016/0044-8486(93)90011-M

[58] Leon, K.A. (1986) Effect of Exercise on Feed Consumption, Growth, Food Conversion, and Stamina of Brook Trout. The Progressive Fish-Culturist, 48, 43-46. https://doi.org/10.1577/1548-8640(1986)48<43:EOEOFC >2.0.CO;2

[59] He, W., Xia, W., Cao, Z.-D. and Fu, S.-J. (2013) The Effect of Prolonged Exercise Training on Swimming Performance and the Underlying Biochemical Mechanisms in Juvenile Common Carp (Cyprinus carpio). Comparative Biochemistry and Physiology, Part A, 166, 308-315. https://doi.org/10.1016/j.cbpa.2013.07.003

[60] Evenson, M.D. and Ewing, R.D. (1993) Effect of Exercise of Juvenile Winter Steelhead on Adult Returns to Cole River Hatchery, Oregon. The Progressive Fish-Culturist, 55 , 
180-183. https://doi.org/10.1577/1548-8640(1993)055<0180:EOEOJW >2.3.CO;2

[61] Davison, W. and Goldspink, G. (1977) The Effect of Prolonged Exercise on the Lateral Musculature of the Brown Trout (Salmo trutta). Journal of Experimental Biology, 70, 1-12.

[62] Cresswell, R.C. and Williams, R. (1983) Post-stocking Movements and Recapture of Hatchery-Reared Trout Released into Flowing Waters-Effect of Prior Acclimation to Flow. Journal of Fish Biology, 23, 265-276. https://doi.org/10.1111/j.1095-8649.1983.tb02904.x

[63] Houlihan, D.F. and Laurent, P. (1987) Effects of Exercise Training on the Performance Growth, and Protein Turnover of Rainbow Trout (Salmo gairdneri). Canadian Journal of Fisheries and Aquatic Science, 44, 1614-1621.

https://doi.org/10.1139/f87-195

[64] Deschamps, M.-H., Labbé, L., Baloche, S., Fouchereau-Péron, M., Dufour, S. and Sire, J.-Y. (2009) Sustained Exercise Improved Vertebral Histomorphometry and Modulates Hormonal Levels in Rainbow Trout. Aquaculture, 296, 337-346. https://doi.org/10.1016/j.aquaculture.2009.07.016

[65] Ibarz, A., Felip, O., Fernández-Borràs, J., Martín-Pérez, M., Blasco, J. and Torrella, J.R. (2011) Sustained Swimming Improves Muscle Growth and Cellularity in Gilthead Sea Bream. Journal of Comparative Physiology B, 181, 209-217. https://doi.org/10.1007/s00360-010-0516-4

[66] Parker, T.M. and Barnes, M.E. (2014) Rearing Velocity Impacts on Landlocked Fall Chinook Salmon (Oncorhynchus tsawytscha) Growth, Condition, and Survival. Open Journal of Animal Sciences, 4, 244-252.

https://doi.org/10.4236/ojas.2014.45031 